\title{
BENTUK PENGELOLAAN HUTAN DENGAN KEARIFAN LOKAL MASYARAKAT ADAT TUGUTIL
}

(Studi Kasus Masyarakat Adat Tugutil di Dusun Tukur-tukur Kecamatan Wasile Timur Kabupaten Halmahera Timur)

\author{
Sabaria Niapele \\ Staf Pengajar FAPERTA UNIV. NUKU-Tidore, $e$-mail: -
}

\begin{abstract}
ABSTRAK
Masyarakat adat memiliki motivasi yang kuat dalam melindungi hutan dibandingkan pihak-pihak lain karena menyangkut keberlanjutan kehidupan mereka, pengetahuan asli yang dimiliki bagaimana memelihara dan memanfaatkan sumberdaya hutan yang ada di dalam habitat mereka. Memiliki hukum adat untuk ditegakkan serta memiliki kelembagaan adat yang mengatur interaksi harmonis antara mereka dengan ekosistem hutannya. penelitian ini bertujuan untuk mengetahui bentuk-bentuk kearifan lokal dalam mengelola hutan. untuk mengetahui bagaimana cara dalam memelihara dan mempertahankan kearifan lokalnya dalam mengelola hutan dan pemanfaatan tumbuhan hutan. Penelitian dilaksanakan di Dusun Tukur-Tukur Kecamatan Wasile Timur Kabupaten Halmahera Timur. Metode penelitian yang digunakan adalah eksplorasi deskriptif dan pengambilan data dengan metode random sampling dan metode trigulasi. Data dianalisis dengan metode deskriptif kualitatif. Berdasarkan hasil penelitian maka dapat diketahui bentuk-bentuk kearifan lokal masyarakat adat tugutil antara lain sebagai berikut : Larangan merusak sagu raja, Buko, Nonaku, Ma ngadodo gomu pahiyara (batasan pemeliharaan). untuk memelihara dan mempertahankan kearifan lokal dalam mengelola hutan adalah dengan cara sebagai berikut: Penuturan lisan, Sangsisangsi adat, Penerapan secara langsung (praktek). ada terhadap 149 tumbuhan yang dimanfaatkan. yang dibagi atas 100 tumbuhan bahan pangan (71 spesies)dan 49 sumber tumbuhan obat (45 spesies).
\end{abstract}

Kata Kunci: Kearifan Lokal, Pengelolaan hutan, Lingkungan

\section{PENDAHULUAN}

\subsection{Latar Belakang}

Luas wilayah indonesia yang mencapai 195 juta hektar, diataranya $65 \%$ atau sekitar 144,0 juta hektar merupakan kawasan hutan. Dengan demikian, di Negara Indonesia sumber daya hutan menjadi potensi kekayaan alam yang sangat penting, sebab berfungsi sebagai pengatur tata guna air, perlindungan terhadap erosi tanah dan lingkungan, serta mengandung berbagai sumber daya alam yang pontensial bagi pembangunan nasional.

Hutan diidentifikasikan sebagai suatu lahan yang sangat luas ditumbuhi oleh pohonpohon secara keseluruhan merupakan persekutuan hidup alam hayati beserta lingkungannya dan ditetapkan oleh pemerintah sebagai hutan (UU 41 Thn. 1999).

Bagian terbesar dari sebuah ekosistem ialah kumpulan tetumbuhan dan binatang yang secara bersama-sama dan otomatis membentuk suatu masyarakat tumbuhan dan binatang yang dinamakan komunitas. (Resosoedarmo dkk.1989).

Komunitas terdiri atas berbagai organisme yang saling berhubungan pada suatu daerah tertentu. Kesatuan dari berbagai jenis organisme itu bisa menjadi perwakilan dari suatu tipe komunitas ataupun ekosistem tertentu yang memmiliki karakteritik tertentu 


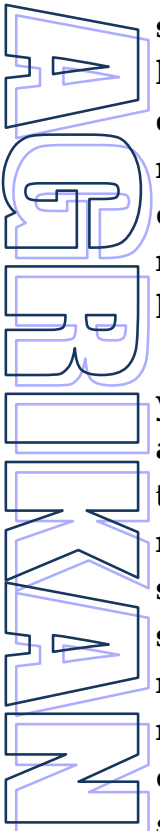

sehingga menjadi pembeda antara satu komunitas ekosistem dengan komunitas dan ekosistem lainnya. Keanekaragaman hayati merupakan sumber daya alam yang dapat dimanfaatkan untuk berbagai keperluan manusia dengan melihat kaidah-kaidah kelestarian hutan.

Hubungan masyarakat asli atau lokal yang dekat dengan lingkungan sumber daya alam membuat mereka memiliki pemahaman tersendiri terhadap sistem ekologi dimana mereka tinggal. Lingkungan sendiri seharusnya dipersepsikan bukan hanya sekedar sebagai objek yang harus digunakan untuk memenuhi kebutuhan manusia (human centris), melainkan juga harus dipelihara dan ditata demi kelestarian lingkungan itu sendiri (eco sentris). Oleh karena itu, adanya ikatan antara manusia dengan alam akan melahirkan pengetahuan dan pikiran bagaimana mereka memperlakukan alam lingkungannya. Mereka menyadari betul akan segala perubahan dalam lingkungan sekitarnya dan mampu mengatasinya demi kepentingannya. Salah satu cara ialah dengan mengembangkan sikap kelakuan, gaya hidup, dan tradisi-tradisi yang mempunyai implikasi positif terhadap pemeliharaan dan pelestarian lingkungan hidup (Salim, 1979). Tradisi - tradisi inilah yang disebut sebagai salah satu aplikasi sebuah kearifan lokal.

Masyarakat adat dalam tradisi modern dikenal dengan istilah "indigenous society", yang secara harafiah berarti seseorang yang di anggap memiliki keaslian kehidupan. Adat dapat diartikan "pribumi" digunakan semata-mata sebagai suatu kata sifat, orangorang yang berasal dari suatu kultur atau kelompok menghormati asal usul mereka dengan perasaan, pemaknaan dan pengertian yang mendalam atas suatu wilayah yang mereka tempati. Masyarakat adat memiliki karakter yang membatasi diri dan mengidentikan diri mereka sebagai sebuah kelompok kecil yang memiliki otoritas dalam menempati sebuah wilayah tertentu berdasarkan ukuran-ukuran yang disepakati secara konvensional (Aman, 2008).

Keberadaan masyarakat adat tersebar di berbagai penjuru Nusantara dengan keragaman ekosistem tempat mereka hidup. Mayoritas masyarakat adat mewarisi tanah ulayat milik nenek moyang mereka dengan sistem hidup yang terkadang sangat ketat diberlakukan. Pedalaman hutan hujan tropis, pinggiran hutan dan sepanjang garis pantai adalah beberapa lokasi dimana masyarakat adat tinggal, menetap permanen, nomaden dan semi nomaden. Sehingga kita boleh menyimpulkan bahwa selama ini, $30 \%$ hutan asli Indonesia dijaga dan dilestarikan oleh Masyarakat Adat. Selama waktu itu pula muncullah kecerdasan dan local spirit bagaimana kita mengelola dan melesatarikan sumber daya alam khususnya sumber daya hutan yang dimiliki Indonesia. Masyarakat adat merupakan suplemen dari Negara Indonesia, bukan komplemen.

Masyarakat adat memiliki motivasi yang kuat dalam melindungi hutan dibandingkan pihak-pihak lain karena menyangkut keberlanjutan kehidupan mereka, pengetahuan asli yang dimiliki bagaimana memelihara dan memanfaatkan sumberdaya hutan yang ada di dalam habitat mereka. Memiliki hukum adat untuk ditegakkan serta memiliki kelembagaan adat yang mengatur interaksi harmonis antara mereka dengan ekosistem hutannya.

Masyarakat adat Togutil memiliki pola kehidupan secara nomaden, dan karena itu kehidupan mereka masih sangat tergantung pada keberadaan hutan-hutan asli. Pada umumnya mereka bermukim secara berkelompok di sekitar sungai Dodaga dan memiliki wilayah teroterial kekuasaan yang masing-masing kelompok saling menghormati wilayah Teroterial masing-masing kelompok. Rumah-rumah mereka terbuat dari kayu, bambu dan beratap daun palem sejenis Livistonia sp. Umumnya rumah mereka tidak berdinding dan berlantai papan panggung.

Walaupun mereka masih primitif karena pola hidup secara nomaden tanpa merubah dan merusak alam, namun keberadaan mereka seperti itu telah memberikan pelajaran berharga kepada kita semua dalam hal melestarikan hutan. Seakan-akan mereka berpesan; janganlah sekali-kali merusak alam (Latif, 2009).

Dalam pandangan masyarakat adat Tugutil bahwa tumbuh-tumbuhan pada dasarnya perlu dan ingin diperhatikan atau diperlakukan secara baik. Karena diyakini 
bahwa perlakuan yang baik terhadap tumbuhan yang dimanfaatkan maka setiap tumbuhan yang dipelihara akan memberikan keuntungan dan kenyamanan bagi manusia. Merusak atau memanfaatkan secara berlebihan berarti akan merusak sumber kehidupan yang dimiliki sehingga akan menyulitkan kehidupan anak cucu (ngofa ngofaka). Pada umumnya masyarakat adat Tugutil telah mengetahui dan memanfaatkan berbagai jenis tumbuh-tumbuhan untuk kelangsungan hidupnya sehari-hari. Berangkat dari pentingnya penerapan kearifan lokal dalam menjaga kelestarian lingkungan oleh masyarakat adat maka dari Gambaran ini yang mendasari perhatian dan pemikiran penulis untuk melakukan penelitian dengan judul "Bentuk Pengelolaan Hutan Dengan Kearifan Lokal Masyarakat Adat Tugutil (Studi Kasus Masyarakat Adat Tugutil di Dusun Tukur Tukur Kecamatan Wasile Timur Kabupaten Halmahera Timur).

1.2. Tujuan dan Manfaat Penelitian

1.3.1. Tujuan Penelitian

1. Mengetahui Bentuk-bentuk kearifan lokal yang ada pada masyarakat adat Tugutil di Dusun Tukur-tukur dalam mengelola hutan?

2. Mengetahui bagaimana masyarakat adat Tugutil di Dusun Tukur-tukur dalam memelihara dan mempertahan kearifan lokalnya dalam mengelola hutan?

3. Mengetahui jenis-jenis tumbuhan yang dimanfaatkan oleh masyarakat adat Tugutil di Dusun Tukur-tukur?

1.3.2. Manfaat Penelitian

1. Dari segi akademis, Hasil yang diperoleh dari penelitian ini juga diharapkan dapat menjadi salah satu sumber informasi dan bahan acuan untuk melakukan penelitianpenelitian selanjutnya yang berkaitan dengan masyarakat adat tugutil.

2. Dari segi sosial, dapat diperoleh penjelasan mengenai lingkungan masyarakat setempat dan seberapa jauh kelestarian sumber daya alam dipengaruhi oleh kearifan lokal masyrakat setempat.

3. Dari segi praktis, Hasil penelitian ini di harapkan dapat dijadikan sebagai bahan pertimbangan dan masukan bagi pemerintah setempat dalam menentukan suatu kebijakan yang tepat dalam hal pengembangan dan memperdayakan masyarakat adat Tugutil ke depan.

\section{METODE PENELITIAN}

\subsection{Waktu dan Tempat Penelitian}

Penelitian ini dilaksanakan pada bulan Januari - April 2013. Di Dusun Tukur-tukur Kecamatan Wasile Timur Kabupaten Halmahera Timur .

\subsection{Alat dan Bahan}

Alat dan bahan yang digunakan dalam penelitian ini antara lain :

1. Kamera digital untuk mendokumentasikan Kegiatan penelitian.

2. Alat tulis menulis untuk mencatat data di lapangan.

3. Panduan Kuisioner yang digunakan sebagai bahan acuan dalam pengumpulan data melalui proses wawancara terhadap responden (Masyarakat adat dimana bahasa yang digunakan disesuaikan).

\subsection{Obyek penelitian}

Kelompok masyarakat adat Tugutil yang berada di dusun tukur-tukur Kecamatan Wasile Timur Kabupaten Halmahera Timur.

\subsection{Metode Penelitian}

Adapun metode yang digunakan metode penelitian yang digunakan adalah eksplorasi deskriptif, dengan pertimbangan bahwa untuk dapat mendokumentasikan pengetahuan masyarakat tentang bentukbentuk kearifan lokal, cara mempertahakan kearifan lokal dan pengelolaan tumbuhtumbuhan pangan dan obat-obatan membutuhkan penggalian informasi yang tepat dan kajian cermat dan mendalam.

\subsection{Jenis dan Sumber Data}

Data primer merupakan data yang diperoleh dari masyarakata adat Tugutil dengan metode penentuan sampel dari jumlah masayarakata adat Tugutil serta menggunakan panduan quesioner. Sementara data sekunder data yang diambil dari instansi terkait yang berkaitan dengan penelitian ini. 
2.6. Metode Pengambilan data

Metode pengambilan data dilokasi penelitian yaitu :

1. Metode Random sampling (acak).

Jumlah sampel yang diambil yaitu sebanyak $50 \%$ dari jumlah seluruh Kepala keluarga yang berada di Dusun Tukur-Tukur Kec. Wasile Timur Kab. Halmahera timur. Jumlah Kepala keluarga di Dusun Tukur-Tukur Kec. Wasile Timur Kab. Halmahera Timur sebanyak 42 KK sehingga sampel yang diambil yaitu sebanyak $21 \mathrm{KK}$.

2. Metode Triangulasi (gabungan)

Teknik pengambilan data dengan cara memadukan beberapa teknik pengambilan data seperti pengamatan secara langsung dilapangan (observasi), wawancara dan penelusuran dokumen. Metode ini sangat diperlukan dengan pertimbangan bahwa setiap metode pengumpulan data mempuyai kelebihan dan kelemahan, sehingga data yang diperoleh akan lebih valid (Sitorus 1989).

\subsection{Analisis data}

Data yang di peroleh dalam penelitian ini akan di analisis dengan mengunakan analisis deskriptif kualitatif

\section{HASIL DAN PEMBAHASAN}

3.1. Sejarah Singkat Dusun Tukur-Tukur

Kata Dusun Tukur-tukur berasal dari bahasa Tobelo yaitu Tukurino artinya melintang menurut masyarakat Dusun Tukurtukur terbentuk dari sekelompok orang yang tinggal di lokasi tersebut pada suatu hari ada pohon yang jatuh melintang dan menutupi jalan keluar masuk ke lokasi di mana pohon yang roboh tadi di tumbuhi oleh banyak jamur yang kemudian di pungut oleh warga yang lewat lokasi tersebut dalam bahasa setempat di sebut (Hogota hiruba hoi tukurino horai hi wango)

Masyarakat adat Tugutil di Dusun Tukur-tukur mulai dimukimkan sejak tahun 1994. Di mana masyarakat tersebut mulai dibina dan diarahkan untuk tidak lagi hidup berpindah pindah tempat hingga saat ini. Namun pada tahun 1999 terjadi konfik horizontal sehingga membuat mereka semua memilih untuk pergi meningalkan Dusun
Tukur-tukur dan kemudian menetap di Dusun Totodoku /Totipah lokasinya lebih masuk lagi ke dalam hutan. Namun pada tahun 2004 upaya untuk mengembalikan meraka ke Dusun Tukur-tukur dilakukan lagi tapi hanya sedikit yang mau kembali dan menetap lagi. Sedangkan yang lain lebih memilih tetap tinggal di Dusun Totodoku dan Totipah.

Untuk masyarakat adat Tugutil yang tinggal di Dusun Tukur-tukur berjumlah 42 kk yang sudah tercatat secara resmi di Kantor Desa Dodaga . Di mana pada tahun 2012 masyarakat adat di Dusun Tukur-tukur mendapat bantuan raskin dari Pemerintah Kabupaten Halmahera Timur.

3.2. Kelompok Masyarakat Adat Tugutil dan Wilayah Kekuasaan

a. Kelompok Masyarakat Adat Tugutil Tukur-Tukur

Masyarakat adat Tugutil di dusun tukur tukur mulai dimukimkan sejak tahun 1994. Di mana masyarakat tersebut mulai dibina dan diarahkan untuk tidak lagi hidup berpindah pindah tempat hingga saat ini. Namun pada tahun 1999 terjadi konfik horizontal sehingga membuat mereka semua memilih untuk pergi meningalkan Dusun Tukur-tukur dan kemudian menetap di Dusun Totodoku/ Totipah lokasinya lebih masuk lagi kedalam hutan. Namun pada tahun 2004 upaya untuk mengembalikan meraka ke Dusun Tukur-tukur dilakukan lagi tapi hanya sedikit yang mau kembali dan menetap lagi.

Untuk masyarakat adat Tugutil yang tinggal di Dusun Tukur-tukur berjumlah 42 kk yang sudah tercatat secara resmi di kantor Desa Dodaga . Di mana pada tahun 2012 masyarakat adat di Dusun Tukur-tukur mendapat bantuan raskin dari Pemerintah Kabupaten Halmahera Timur.

Kelompok masyarakat adat Tugutil Tukur-tukur memiliki wilayah kekuasaan dengan luas $10.000 \mathrm{Ha}^{2}$ meliputi Woka Jaya, Toboino, Sungai Dodaga hingga sampai tapal batas gunung selamat pagi.

b. Kelompok Masyarakat Adat Tugutil Totodoku/Totipah

Masyarakat adat Tugutil di Dusun Totodoku/Totipah Di mana masyarakat tersebut mulai dibina dan diarahkan pada 
tahun 2005 untuk tidak lagi hidup berpindah pindah tempat hingga saat ini.

Kelompok masayarakat adat Tugutil Totoduku/Totipah memiliki wilayah kekuasaan meliputi disekitar gunung es, gunung uni-uni sampai di sekitar wilayah transmigrasi wayamli

c. Kelompok Masyarakat Adat Tugutil Raki Lamo

Masyarakat adat Tugutil di Raki Lamo, merupakan kelompok masyarakat adat Tugutil yang bermukim disekitar Sungai kalimeja dimana meraka mengusai kawasan sagu raja yang merupakan sumber pokok utama untuk memenuhi kebutuhan karbohidrat. Untuk kelompok masyarakat adat Tugutil di Dusun Raki Lamo tidak sebanyak kelompokkelompok lainnya. Untuk masyarakat adat tugutil yang tinggal di dusun raki lamo berjumlah $10 \mathrm{kk}$.

Kelompok masyarakat adat Tugutil di Dusun Raki Lamo memiliki wilayah kekuasaan meliputi Akedaga, Dakaino sepanjang sungai Kali meja dan Gulapapo.

d. Kelompok Masyarakat Adat Tugutil O'oboy

Masyarakat adat Tugutil di Dusun O'Oboy, merupakan kelompok masyarakat adat Tugutil yang bermukim di sekitar Sungai o'Oboy.

Untuk masyarakat adat Tugutil yang tinggal di Dusun O'oboy berjumlah sekitar 46 kk yang sudah tercatat secara resmi di Kantor Desa Tutuling Jaya .

Kelompok masayarakat adat Tugutil di Dusun O'oboy memiliki wilayah kekuasaan meliputi Tutuling Jaya, sepanjang sungai O'oboy hingga hutan di sekitar Lolobata.

3.3. Karakteristik Sosial, Ekonomi dan Budaya Suku Tugutil

\subsubsection{Pola Pemukiman}

Kesatuan rumah (o tau moi) adalah bentuk pemukiman atau tempat tinggal yang terkecil bagi masyarakat Tugutil sebagai tempat tinggal, pusat aktivitas individunya sebagai warga masyarakat. Tiap o tau moi dihuni oleh satu keluarga inti yang tandai dengan sebuah atau beberapa bangunan gubuk yang merupakan milik dari keluarga inti tersebut.
Struktur fisik rumah masyarakat adat Tugutil dibagi atas tipe sederhana, sedang dan lengkap. Tipe paling sederhana hanya terdiri dari satu bangunan (gubuk / o tau ma amoko) dengan ukuran 1,5 × $2 \mathrm{~m}$ yang terbuka semua sisinya. Didalam gubuk tersebut terdapat balaibalai (o dangiri) sebagai tempat menerima tamu sekaligus tempat tidur. Dapur hanya berupa sebuah tungku api (o rikana) yang pada malam hari berfungsi sebagai perapian untuk pengusir nyamuk dan penghangat badan. Tipe sedang biasanya ditandai dengan penambahan 1 gubuk untuk dapur diluar gubuk utama. Sedangkan Tipe lengkap ditandai dengan penambahan beberapa gubuk biasa untuk tempat tidur anak-anak yang telah dewasa tapi belum berkeluarga atau gubuk untuk tamu.

Martodirjo (1991) mengemukakan bahwa secara umum masyarakat Tugutil mengenal tiga tingkatan bentuk atau konsep tempat tinggal atau pemukiman, yang masing-masing memiliki arti dan fungsi saling mengisi dan melengkapi dalam kehidupan mereka yaitu kesatuan rumah (o tau), kesatuan Pemukiman(o gorere) dan kesatuan hutan (o hogana). Beberapa kesatuan rumah akan membentuk satu kesatuan pemukiman (o gorere moi) dan secara keseluruhan mereka menyatakan dirinya satu kesatuan hutan.

Umumnya mereka membangun tempat tinggal atau pemukiman di tepi sungai di dalam kawasan hutan atau dalam jarak 20 - 100 $m$ dari tepi sungai. Kesatuan rumah atau kesatuan pemukiman tersebut biasanya dibangun dalam jarak yang berjauhan yaitu berkisar 20 sampai 500 atau lebih.

Menurut Martodirdjo (2001) Jarak tersebut bisa lebih dari $500 \mathrm{~m}$ jarak terjauh antara 1- $6 \mathrm{~km}$, namun berdasarkan hasil pengamatan selama penelitian diperoleh data jarak antara satuan pemukiman ternyata ada yang lebih dari $6 \mathrm{~km}$ yaitu antara Satuan pemukiman Totodoku dan Tukur-tukur. Pola Pemukiman tradisional ini dibangun melingkar yang berdekatan atau berhadapan namun adapula yang menyebar dengan jarak antar rumah 10-50 $\mathrm{m}$ dalam satu satuan pemukiman.

\subsubsection{Mata Pencaharian dan Tingkat Pendapatan Masyarakat \\ Saat ini sebagian masayarakat adat} Tugutil merupakan petani (Tugutil kategori 


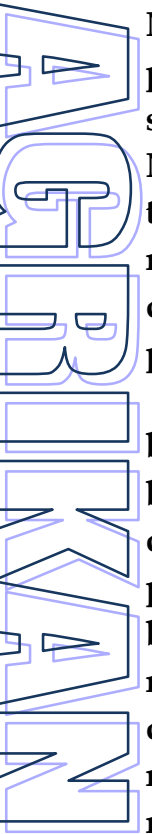

Menetap) dan sebagian lagi masih tergantung pada hasil hutan meskipun telah mengenal sistem bercocok tanam (Tugutil kategori Menetap sementara). Mata pencaharian tambahan adalah berburu binatang damar maupun telur maleo untuk dijual atau ditukarkan dengan penduduk di kampung pada saat hari pasar.

Tingkat pendapatan penduduk berdasarkan hasil penelitian dilapangan sangat bervariasi yaitu antara Rp. $\mathbf{5 0 . 0 0 0}$ sampai dengan Rp. 750.000,- per bulan. Sumber penghasilan umumnya berasal penjualan hasil buruan atau hasil yang diperoleh dari hutan maupun dari hasil kebun yang dikelola disekitar satuan pemukiman atau satuan rumahnya. Pendapatan diatas $\mathbf{5 0 0 . 0 0 0}$ merupakan pendapatan masyarakat adat Tugutil menetap yang memiliki profesi sebagai petani kopra maupun usaha sampingan lainnya seperti pedagang dan tukang ojek.

\subsubsection{Pola Kepemilikan Lahan.}

Bagi Masyarakat adat Tugutil pola kepemilikan lahan dibagi atas : milik sendiri (ahiraki) dan lahan milik bersama (miaraki). Lahan milik sendiri selain merupakan warisan turun-temurun dari keluarga, ada juga merupakan lahan yang diperoleh dari pemerintah melalui program pemukiman kembali yang dilakukan pada tahun 1980. Umumnya masyarakat adat Tugutil memiliki lahan atau kebun milik sendiri tidak lebih dari 2 Ha. Dari hasil wawancara ternyata rata-rata petani yang memiliki lahan atau kebun tetap dengan luas 0,25 - 1,25 Ha. Bagi masyarakat Tugutil tipe menetap sementara umumnya memiliki lahan atau kebun yang kurang dari 0,25 ha. Lahan yang menjadi milik sendiri dapat diperjual belikan sesuai kebutuhan, namun bagi lahan milik bersama tidak boleh di perjual belikan.

Lahan milik bersama dalam masyarakat adat Tugutil biasanya berupa areal hutan atau suatu kawasan dimana terdapat sumber mata pencaharian berupa bahan makanan pokok atau areal perburuan yang biasanya sebut "mialolingiri". Bagi masyarakat adat Tugutil suatu areal hutan atau lahan yang telah dijadikan sebagai wilayah (mialolingiri) yaitu adalah milik bersama yang harus dimanfaatkan dan dikelola secara bersama.

Lahan milik bersama dapat pula berupa suatu lahan yang ditetapkan secara bersamasama untuk dikelola satu jenis tanaman atau beberapa jenis tanaman yang telah disepakati bersama-sama yang disebut kebun jemaat, atau pun kebun/lahan masyarakat.

\subsection{Bentuk - Bentuk Kearifan Lokal Masyarakat Adat Tugutil}

3. 4. 1. Larangan Merusak Kawasan Sagu Raja

Berdasarkan hasil wawancara terhadap responden dan beberapa informan bahwa dari dahulu sampai sekarang setiap orang yang masuk dalam suatu areal kawasan Sagu Raja Kali Meja dilarang memasuki dan merusak. Hal ini karena kawasan tersebut merupakan areal Mialolingiri (kawasan sumber pencaharian bahan makanan pokok) Masyarakat adat Togutil yang harus dapat dimanfaatkan secara bersama-sama dan dijaga kelestariaanya. Setiap orang yang tertangkap melakukan pengrusakan maka dia akan dikenakan sanksi sesuai ketentuan yang berlaku yaitu berupa penyitaan semua peralatan memukul Sagu ataupun denda berupa uang yang telah disepakati jumlahnya.

Bagi orang yang akan memasuki kawasan meskipun tidak melakukan aktivitas apapun di dalamnya tersebut harus mendapat izin dari kepala suku (o dimono). Masyarakat Tugutil menyadari bahwa merusak kawasan sagu raja merupakan pengrusakan terhadap sumber daya alam sekaligus penghianatan terhadap leluhur sebagai pemilik. Bentuk larangannya yaitu apa bila ada sekelompok masyarakat tersebut masuk kekawasan sagu raja untuk mengambil sagu terus tidak meminta izin pada Tetua adat (o'dimono) maka meraka akan mendapat sangsi atau di bunuh kelompok lain yang menjaga kawasan sagu raja, bentuk-bentuk sangsi diatas masih digunakan dan bentuk-bentuk sangsinya sudah menurun dari dibunuh menjadi berupa denda.

Umumnya orang lebih mengenal sebagai boboso atau dalam bahasa Togutil Larangan tersebut disebut bohono. Istilah Bohono sendiri artinya sangat luas karena larangan ini juga berlaku untuk pekerjaan, ataupun perkawinan 
dengan kekerabatan dekat. Larangan Merusak Kawasan sagu raja dalam bahasa Togutil di sebut : Bohono nasrusaha dumule opeda makoano atau Mihigu maya ua mangi opeda idimono (kalimat dalam terjemahan bebas berarti "dilarang untuk merusak kawasan sagu raja" atau dilarang merusak tanaman sagu tanpa izin dari orang yang dituakan/ kepala suku)

Meskipun saat ini banyak masyarakat adat Togutil yang tidak mengetahui hal ini namun dalam praktek kesehariannya mereka tetap menjaga kelestarian kawasan rawa sagu kali meja ini dengan pemanfaatan sagu hanya untuk mengambil kebutuhan pokok (sagu) saja sedangkan untuk keperluan atau kebutuhan lainnya saat ini sebagian masyarakat adat Togutil (Dodaga) telah melakukan penanaman di kebun (dumule).

3.4.2. Buko

Buko adalah istilah yang menjelaskan adanya larangan untuk merusak atau mengambil tanaman dalam suatu kebun atau kawasan tertentu dalam satu periode waktu tertentu pula. Buko ini umunya dilakukan pada areal atau kawasan yang menjadi milik pribadi maupun yang umum. Suatu kawasan yang telah dikenai Buko biasanya ditandai dengan tanda khusus seperti rumah-rumahan kecil berukuran 50 x $50 \mathrm{~cm}$ lalu digantungkan sebuah botol yang diikat pita/kain kecil atau adanya pohon tertentu yang digantung botol dengan pita kecil atau tanda khusus lainnya. Tanda ini kemudian diletakkan di setiap penjuru jalan menuju ke kawasan yang dilarang baik kebun milik sendiri (Dumule), Dumule ngone matamata (kebun milik bersama) ataupun areal mialolingiri. Bila ada yang melanggarnya akan sakit ataupun mengalami hal-hal yang tidak menyenangkan ataupun bahkan dapat membayakan dirinya. Larangan ini berlaku umum bagi siapa saja tidak terbatas pada masyarakat adat Togutil.

Pemasangan Buko umumnya dilakukan secara perorangan maupun kelompok dengan maksud untuk melindungi jenis-jenis tanaman atau sumber mata pencaharian yang dimiliki agar tidak dirusakkan atau diambil dalam jangka waktu tertentu, sekaligus sebagai bentuk penghormatan terhadap leluhur. Pemasangan buko biasanya dilakukan oleh pemilik kebun sendiri, dukun atau o dimono (pemimpin adat) yaitu berupa peletakan tanda Buko di areal dimana sering dilalui masyarakat atau ditempat yang mudah dilihat. Tidak ada upacara ritual adat apapun untuk dalam pemasangan buko. Adanya Buko ini maka secara tidak langsung sebenarnya masyarakat telah melakukan upaya mengeksploitasi keanekaragaman tumbuhan secara bijaksana atau tidak berlebihan.

Meskipun tidak ada sanksi yang diatur dalam aturan adat bagi pelanggarnya namun masyarakat adat Togutil sangat percaya bahwa bila ada yang melanggar akan bisa sakit atau mengalami hal-hal yang tidak baik bahkan dapat mencelakai dirinya. Itulah sebabnya mereka sangat menghormati ataupun menghindari melakukan pelanggaran. Selain itu setiap anggota masyarakat yang pasti dikenai nagimi atau denda baik untuk lahan pribadi maupun lahan bersama Kebiasaan membayar denda ini merupakan suatu hal yang sudah sering dilakukan dalam kehidupan masyarakat adat Togutil apabila melakukan pelanggaran terhadap suatu lahan milik pribadi biasanya berhubungan langsung dengan pemiliknya. Bila itu merupakan lahan masyarakat secara umum atau areal Mialolingiri maka pembayaran denda di lakukan di depan $o$ dimono (orang yang dituakan/semacam kepala suku). Denda tersebut akan dimanfaatkan untuk keperluan bersama.

Bila dikaji lebih dalam sebenarnya sistem ini dapat bermanfaat bila diterapkan bagi upaya pelestarian plasma nutfah terutama bagi jenis-jenis plasma nutfah tumbuhan yang bernilai ekonomis tinggi ataupun yang berpotensi untuk dikembangkan. Namun hal ini tentu saja diperlukan sosialisasi lebih lanjut dan harus ikuti dengan adanya suatu aturan yang jelas atau minimal aturan yang disepakati disepakati bersama. Hal ini disebabkan karena sistem buko ini dalam kenyataannya masih dipahami dan dikaitkan dengan hal-hal yang bersifat magis dan belum dapat diterima oleh semua kalangan masyarakat terutama masyarakat lokal lainnya.

Sebagaimana halnya masyarakat adat Togutil, Adat budaya yang mengarah keperlindungan lingkungan dalam masyarakat sebenarnya masih nampak dalam keseharian masyarakat maluku utara pada umumya antara 


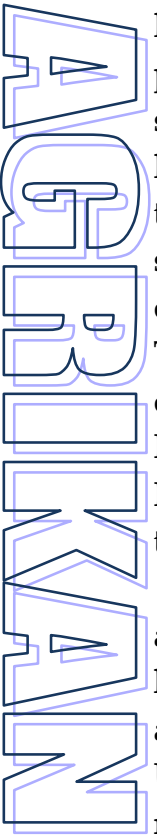

lain budaya adat "Sasi", "Matakao", "Uru", dan penentuan waktu panen sesuatu tanaman secara bersama-sama, atau penanaman tanaman langka dan tebang pilih. Budaya ini ternyata telah menahan laju kepunahan tanaman, seperti ditemukannya beberpa pohon tanaman cengkeh AFO yang telah berumur 400 tahun di Ternate, hutan pala di Calabay Bacan dan hutan cengkeh di Kabosa Bacan, Dokiri di Tidore dan Halmahera serta hutan kenari di Bacan dan Halmahera yang telah berumur sekitar 350 tahun (Hadad et al. 2002).

Konsep pandangan hidup masyarakat adat Togutil bahwa tumbuhan sebagaimana halnya manusia diyakini memiliki jiwa dalam arti bahwa tumbuhan juga berhak untuk hidup. Untuk itu maka manusia harus dapat memperhatikan ataupun memanfaatkan secara bijaksana karena sebagai-mana sumberdaya lainnya seperti tanah dan air, tumbuhan adalah sumber kehidupan bagi manusia. Anak cucu (o ngofa-ngofaka) atau dapat disebut juga manusia yang masih hidup tidak boleh menguasainya secara berlebihan, namun berkewajiban untuk memanfaatkan secara bijaksana bagi kehidupan mereka. Hal ini bermakna bahwa tidak boleh melakukan kerusakan di areal atau kawasan yang menjadi milik bersama. Kewajiban memelihara sumberadaya alam termasuk tumbuhan erat kaitannya kepercayaan asli suku ini yang masih melekat dalam kehidupan masyarakat adat Togutil. Konsep penghormatan terhadap leluhur masih tetap berpengaruh dalam kehidupan masyarakat adat Togutil terutama berkaitan dengan pemanfaatan sumberdaya alam yang dimiliki bersama.

\subsubsection{Nonaku (Tanda lahir)}

Nonaku merupakan suatu tradisi dimana setiap anak yang lahir dalam suatu kelompok diberi tanda dengan cara menanam pohon di tempat dimana bayi dilahirkan dan apa bila bayi dilahirkan tersebut meninggal maka kelompok tersebut akan meningalkan tempat tersebut dan mencari tempat lain sebagai tempat tinggal baru. Tradisi nonaku dilakukan sebagai ungkapan rasa syukur kepada Jou Madi $\mathrm{Hutu}$ atas anugerah31- yang telah diberikan. Tradis ini terus dijaga dan dipertahankan hingga saat ini.
Nanaku juga berfungsi untuk mengetahui umur seorang anak yang lahir kemudian di tanam pohon tersebut dan sebagai tanda kenangan bagi kelompok yang pernah tinggal di daerah tersebut. Ketika pohon yang ditanam sudah besar maka pohon tersebut merupakan hak untuk bayi yang dilahirkan di tempat tersebut. Selain itu nonaku juga berfungsi sebagai tanda atas bayi yang meningal dimana ketika kelompok tersebut melewati tempat tersebut dan melihat pohon yang ditanam sebagai tanda lahir maka kelompok tersebut akan mengingat kembali bahwa apabila anak mereka yang meninggal masih hidup maka akan sudah besar seperti pohon yang ditanam.

\subsubsection{Mang Ngadodo Gamu Pahiyara (Batasan} Pemeliharaan)

Dalam hal ini yang menjadi batasan masyarakat adat Togutil adalah batasan akan pengrusakan-pengrusakan lingkungan hutan yang bisa mengakibatkan berkurangnya sumber-sumber kehidupan mereka. Dengan adanya batasan - batasan pemeliharaan akibat kegiatan pengrusakan lingkungan hutan, diharapkan dapat menjadi solusi dalam mengatasi semakin berkurangnya sumbersumber kehidupan yang terkandung didalam hutan. Saat ini yang menjadi permasalahan di dalam masyarakat adat Togutil adalah mulai adanya perubahan-perubahan kultur budaya akibat pola pikir dari sebagian penduduk yang telah mau berbaur dengan masyarakat dari luar. Selain factor-faktor di atas, juga dikarenkan adanya kegiatan pengrusakan hutan dari aktivitas -aktivitas Kegitan pertambangan dengan dalih meningkatkan pembangunan dan peningkatan PAD daerah, yang dilakukan di daerah sekitar hutan tempat tinggal mereka.

\subsection{Cara Memelihara Dan Mempertahankan Kearifan Lokal}

Dalam hal dan memelihara dan mempertahankan kearifan lokalnya masyarakat adat Tugutil, berpegang teguh pada aturanaturan adat yang telah ada dan dijalan oleh para leluhur meraka dimana didalam ada seperangkat aturan-aturan yang mewajiban kepada anak cucu meraka untuk terus menjaga dan mempertahakan kearifan lokal yang ada. Dalam mewariskan kearifan lokal masyarakat 
adat tugutil melakukan dengan berapa hal antara lain sebagai berikut:

\section{Penuturan Secara Lisan}

Penyampaian nilai-nilai kearifan lokal secara lisan yang disampaikan oleh tetua adat (o dimono) lebih mudah diterima dan dilaksanakan oleh masyarakat.

\section{Sangsi-Sangsi Adat}

Sangsi-sangsi adat akan dilaksanakan bila ada masayarakat yang melakukukan melangar peraturan-peraturan adat yang ada. Misalnya pada pelangaranan memasuki kawasan sagu raja tanpa melalui ijin kepada tetua adat (O'Dimono). Maka meraka akan mendapat sangsi atau di bunuh kelompok lain yang menjaga kawasan sagu raja, bentuk-bentuk sangsi diatas masih digunakan dan bentukbentuk sangsinya sudah menurun dari dibunuh menjadi berupa denda (nagimi) sesuai dengan kesepakan antara pelangar dengan tetua adat (O'Dimono).

3. Penerapan Langsung Dilapangan (Praktek) Penerapan lansung maksunya adalah memberikan pelajaran langsung dilapangan bagaimana cara melakukan penerapan dan mempertahankan kearifan lokal yang ada seperti. Buko dimana setiap dilakukan pembukaan wilayah baru atau membuka lahan baru makan harus membuat buko yaitu di tandai dengan memasang tali merah di pohon atau didekat gubuk dimana lahan tersebut dibuka. Selain itu ada juga nonaku yaitu dimana setiap kelahiran generasi baru harus dilakukan ritual menanam pohon bagi keluarga yang bersangkutan dan ini terus dilakukan dan dipraktekan oleh masyarakat adat tugutil Maluku Utara khususnya di Halmahera Timur.

\subsection{Pengetahuan Masyarakat Tentang} Pemanfaatan Tumbuh - Tumbuhan Hutan.

Dalam Pandangan masyarakat adat Tugutil setiap jenis tumbuhan yang ada di sekitar kehidupan manusia memiliki jiwa dan perasaan seperti halnya manusia. Oleh karena itu maka dalam pemanfaatannya harus dilakukan dengan baik. Misalnya bila seseorang akan mengambil atau memanfaatkan sebagian dari suatu tanaman untuk tujuan pengobatan maka dia harus melakukan ritual kecil berupa pemberian makanan dan disertai dengan pengucapan niat sebagai pengahargaan sekaligus permintaan kepada leluhur penghuni tanaman tersebut. Pengambilan atau pemanfaatan tumbuhan tidak dapat dilakukan oleh sembarangan orang. Pengambilan suatu jenis tanaman terutama obat-obatan hanya dilakukan oleh orang-orang tertentu yang memiliki pengetahuan yang baik tentang manfaat dari suatu jenis tumbuhan misalnya seorang gomatere (dukun) secara langsung. Di dalam pemanfatan bagian tanaman pun hanya diambil sesuai kebutuhan dan tidak diperkenankan berlebih-lebihan.

Dalam pandangan masyarakat adat Tugutil bahwa tumbuh-tumbuhan pada dasarnya perlu dan ingin diperhatikan atau diperlakukan secara baik. Karena diyakini bahwa perlaku-kan yang baik terhadap tumbuhan yang dimanfaatkan maka setiap tumbuhan yang dipelihara akan memberikan keuntungan dan kenyamanan bagi manusia. Merusak atau memanfaatkan secara berlebihan berarti akan merusak sumber kehidupan yang dimiliki sehingga akan menyulitkan kehidupan anak cucu (ngofa ngofaka).

Pada umumnya masyarakat adat Tugutil telah mengetahui dan memanfaatkan berbagai jenis tumbuh-tumbuhan untuk kelangsungan hidupnya sehari-hari. Dari Penelitian yang dilakukan diperoleh hasil bahwa masyarakat adat Tugutil telah memanfaatkan jenis tumbuhan pertanian yang dimanfaatkan untuk berbagai keperluan baik sebagai sumber pangan maupun sebagai bahan obat-obatan. Terdapat 149 tumbuh-tumbuhan yang terbagi 100 tumbuh- tumbuhan sumber pertanian (71 spesies) yang dimanfaatkan sebagai sumber pangan dan 49 sumber tumbuh-tumbuhan obat (45 spesies) dimanfaatkan sebagai bahan obat.

Berbagai jenis tumbuhan tidak seluruhnya dimanfaatkan dalam kehidupan sehari-hari. Misalnya dalam kegiatan meramu obat hanya dilakukan pada saat saat tertentu saja. Jenis-jenis tumbuhan yang sangat berpengaruh dalam kehidupan keseharian masyarakat adat Tugutil adalah jenis tumbuhan yang dimanfaatkan sebagai sumber bahan makanan pokok ataupun karbohidrat pengganti bahan makanan pokok. Jenis tumbuhan tersebut misalnya, sagu (Metroxylon sago, Ipomoea batatas, Musa sp dan Xantosoma sp. 
Saat ini seiring dengan adanya perubahan dalam pola kehidupan masyarakat adat Tugutil maka jenis-jenis tumbuhan tersebut diatas selain dimanfaatkan secara subsisten juga telah ada yang dilakukan secara komersil. Dari sekitar 149 jenis tumbuhan yang telah dimanfaatkan oleh masyarakat Tugutil. Terdapat beberapa jenis tanaman yang memiliki kultivar sangat banyak yaitu pisang 16 jenis, mangga 5 jenis dan jambu 4 jenis.

\section{PENUTUP}

4.1. Kesimpulan

1. Bentuk-bentuk Kearifan lokal masyarakat adat Tugutil di Dusun Tukur-tukur Kecamatan Wasile Timur Kabupaten Halmahera Timur. Dalam menjaga dan mengelola hutan adalah sebagai berikut : Larangan merusak Kawasan Sagu Raja, Buko, Nonaku, Ma ngadodo gomu pahiyara (Batasan pemeliharaan)

2. Untuk Memelihara dan mempertahan kearifan lokal dalam mengelola hutan adalah dengan cara sebagai berikut : Penuturan secara lisan, sangsi-sangsi adat, penerapan secara lansung (praktek).
3. Jenis tumbuhan yang dimanfaatkan oleh masyarakat adat Tugutil sebanyak 149 tumbuhan. Yang terdiri atas 100 tumbuhan bahan pangan (71 spesies) dan 49 tumbuhan obat (45 spesies). Pola pemanfaatan sumberdaya (tumbuhan) sebagai bahan makanan utama merupakan milik bersama yang harus dimanfaatkan secara lestari.

4.

4.2. Saran

1. Bagi Pemerintah Kab Halmahera Timur dalam menentukan suatu kebijakan harus tepat dalam hal pengembangan dan memperdayakan masyarakat adat Tugutil ke depan.

2. Pemerintah harus membangun sarana dan prasarana pendukung yang dapat menunjang keberlanjutan nilai-nilai kearifan lokal yang ada pada masyarakat adat Tugutil di dusun tukur-tukur Kec. Wasile Timur.

3. Marilah kita jaga dan lestarikan hutan dan lingkungan untuk anak cucu dan generasi penerus kita.

\section{DAFTAR PUSTAKA}

Aminah, Andi Nur. 2011. Togutil Penghuni Rimba Halmahera. Bataviase.co.id

Anonim ，1940. Mencari kearifan lokal lewat cerpen. http://rimanews.com

Anonim, 2005. Taman Nasional Aketajawe Lolobata Benteng Alami Untuk Melestarikan Keanekaragaman Hayati Khas Maluku Utara. Bogor : Bird Life Indonesia Programme. 2005. Pemulihan lingkungan dengan kearifan local http: pangasuh bumi. com

2009. mengenal orang togutil suku terasing di pulau halmahera http://ternate.wordpress.com 2010. Membangun masyarakat madani berbasis kearifan local di kabupaten brebes http : staff. undip. ac. id

2011. Mengenal lebih dekat suku terasing http: //id. shvoong.com/ social sciences/anthropology.

Anthon Ngarbingan, 2008. Pohon Sebagai Simbol Kelahiran: Mempertimbangkan Pemahaman Lokal tentang Pohon dalam Upaya Pemulihan Kerusakan Hutan, Lomba YPHL, 2008.

David Purmiasa \& Herman Teguh, 2008. Suku Togutil Yang Bersahaja, yang dikutip; www.halmaherautara.com, Edisi 03 Maret 2008.

Djoko Su'ud Sukahar (Pengamat Budaya) ,2008. Suku Asing E Terasing, detikNews, Edisi Kamis, 21 Agustus 2008.(www.koran tempo.com).

Hasanu Simon 2010. Dinamika hutan rakyat di indonesia, pustaka pelajar, Jogjakarta.

Kartini Abd. Karim, Mahmud Thohari, Sumardjo 2006, Pemanfaatan keanekaragaman Genetik tumbuhan oleh masyarakat tugutil di Sekitar taman nasional aketajawe lolobata 
(Utilization of Plant Genetic Biodiversity by Tugutil tribe in Aketajawe Lolobata National Park) Bogor: Media Konservasi Vol. XI, No. 3 Desember 2006 : 1 - 12

Latif, Busranto. 2009. Mengenai "Orang Togutil" Suku Terasing Di Pedalaman Pulau Halmahera. . (www.korantempo.com).

Martodirdjo H. S, 1984. Orang Togutil di Halmahera Tengah, 1984 p.53. ,1985. Organisasi Sosial Orang Togutil di Halmahera Tengah,1985, p.35.

Mus J. Huliselan,1980. Masalah Pemukiman Kembali Suku Bangsa Togutil di Kecamatan Wasilei Halmahera Tengah Sebuah Laporan Pejajagan, Universitas Patimura, Ambon, 1980. 